Canadian Journal of Family and Youth, 6(1), 2014, pp 135-162

ISSN 1718-9748 () University of Alberta

http://ejournals.library.ualberta.ca/index/php/cjfy

\title{
DETERMINED TO BE HOMESTEADERS: A DESCRIPTIVE ANALYSIS OF THE HOMESTEAD RECORDS OF SINGLE WOMEN WHO PURCHASED VOLUNTEER BOUNTY LAND IN SASKATCHEWAN
}

\author{
Sandra Rollings-Magnusson
}

\begin{abstract}
Under the land regulations set out by the Canadian government in 1871, single women $^{1}$ were not eligible to obtain a free homestead of 160 acres in the western Canadian prairie region. Rather, their male counterparts, those who were eighteen years of age and older, were deemed to be acceptable candidates and entitled to qualify for the quarter-sections. However, by 1908, single women finally obtained an opportunity to register for homestead land, follow the homestead regulations, and gain title to property. This was done through The Volunteer Bounty Act of 1908. While the primary purpose of this Act was to benefit Canadian soldiers who had volunteered and fought in South Africa in the Boer War (1899-1902) by granting them 320 acres of free homestead land in the western prairie region, the Act allowed soldiers to name a substitute; that is, any adult individual who would assume full responsibility for the property and follow homestead regulations. In many cases, the purchasers of these lands were women. Given this unique and innovative way for women to obtain homestead land, this paper will provide a descriptive analysis of the efforts made by single Saskatchewan women in their pursuit of gaining title to their own land.
\end{abstract}

Sandra Rollings-Magnusson is a faculty member of the Sociology Department at MacEwan University in Edmonton, AB. She has published numerous journal articles relating to the economic, political and social lives of pioneers in the province of Saskatchewan and has also written a book entitled "Heavy Burdens on Small Shoulders: The Labour of Pioneer Children on the Canadian Prairies (University of Alberta Press, 2009). She would like to thank SSHRC for the funding this project. 
Rollings-Magnusson

\section{Introduction}

In 1867, one of the primary challenges for Prime Minister John A. MacDonald and his newly formed Canadian government, was the settlement of the western Canadian prairie region. ${ }^{2}$ With the threat of American expansionism to the south, the need for an economic stimulation plan that would help to stabilize the new country, and the promise of substantial monetary benefits that could be obtained by encouraging hundreds of thousands of immigrants to settle on the prairies, the Canadian government moved forward to design a formal homestead policy. ${ }^{3}$ Under this policy, the area of the North-west Territories (which eventually became the provinces of Manitoba, Saskatchewan, and Alberta ${ }^{4}$ ) were to be divided into thousands of parcels of 160 $\operatorname{acres}^{5}$ (quarter-sections); each of which would be freely available to any qualified settler. However, there were requirements that potential settlers had to meet. As set out in an Order-inCouncil dated March, 1871: “Any person who is head of a family, or has attained the age of twenty-one years, who is a subject of Her Majesty by birth or naturalization, shall after the first day of May, 1871, be entitled to be entered for one quarter-section...for the purpose of securing a homestead right in thereof” (as cited by Lambrecht 1991: Appendix II).

In addition, the settler applying for this free land was required to pay a $\$ 10.00$ registration fee as well as take physical possession of the land within six months after applying. The settler also had to agree to live on the land for at least six months of every year for five years. In April, 1871, a revision was made to the Order in that the residency requirements were lessened to three years. As time went by, further changes followed. The Orders in Council proclaimed in March and April, 1871 were replaced by the Dominion Lands Act of 1872 and homestead regulations became more restrictive. For example, in 1886 an amendment was instituted which stipulated that homesteaders were to break at least fifteen acres of land and crop 
ten acres within two years (from the date of entry). Plus, homesteaders had to construct a habitable house on the land within the same two year timeframe. In 1891, more revisions were made to the regulations with homesteaders being required to build a habitable home within six months after entering the land and were expected to break forty acres and crop twenty-five within three years. In 1908, rules were changed once more. While the number of acres broken and cropped were decreased to thirty and twenty respectively, a new emphasis in the regulations focused on a homesteader's nationality. They were to indicate whether they were or intended to become British subjects (Lambrecht, 1991).

While this homestead policy, with its ever-changing rules and regulations, offered potential settlers a great opportunity to acquire and own their own land and produce crops ${ }^{6}$, it should be noted that the Orders-in-Council in 1871 and the Dominion Lands Act of 1872 were only directed towards men who wished to homestead. In fact, in order to encourage men to become settlers, an amendment was introduced that lowered the age limit for male applicants to eighteen years in 1874. In comparison, the only way that women could obtain land occurred in 1876, when they became eligible to apply if they could prove to the government that they were heads of their households. ${ }^{7}$ This status (as to whether the woman was an acceptable candidate for the homestead program or not) was to be determined by the government. If the woman's case was found lacking (i.e. she did not have any dependent children or her marital status was questionable), if there were any statements that she made on her application form that caused uncertainty or doubt, then her application would be reviewed and cancelled (Lambrecht, 1991). In other words, outside of this 'head of household' criterion, women were not eligible to apply for a homestead even though men, regardless of marital status or number of dependents, could apply and obtain 160 acres of free land without question. 


\section{Rollings-Magnusson}

The official position that was used to restrict women from the homesteading program came about because women were not legally defined as 'persons' under Canadian law. ${ }^{8}$ The concept of 'persons' only referred to men, and thus because of the wording set out in the Order in Council dated March, 1871, women's rights and abilities to obtain a homestead were limited. ${ }^{9}$ In fact, it was not until 1930 that changes to the homesteading law were made in Alberta that finally allowed any woman over the age of eighteen to take part in the program. As indicated by Cavanaugh (1993), women in Alberta, Saskatchewan and Manitoba had organized a political movement to fight for the rights of women to register for free homestead land in the 1910s. This political movement continued throughout the 1920s, however, they were not successful until 1930 when the province of Alberta changed the law to allow women to obtain free homestead land in that province. According to Jackel (1979), Saskatchewan and Manitoba also changed their policies at that time, however they decided that their remaining lands should be sold rather than be given away as free homestead land. As such, women never had the opportunity in these two provinces to acquire free homesteads like their male counterparts. Unfortunately, even with the change in the homesteading law which benefitted Alberta women, it came too late to be of any real use. Many women in this province found that by 1930 most of the homestead land that had been available had already been distributed ${ }^{10}$, their economic prospects were restricted given that the wheat boom had already occurred in the $1920 \mathrm{~s}^{11}$, and the homesteading program was eliminated soon after they had obtained their rights (Cavanaugh, 1993). ${ }^{12}$

Despite the restrictive homesteading law that had been in place for so many years, a few single women in Saskatchewan were still determined to find a place for themselves in the farming community during that time frame. For example, in 1901, Isabella McInnis ${ }^{13}$, a forty-six year old single woman, tried to apply for homestead land as head of her family; a family which 
consisted of herself and her disabled brother (who she was claiming as a dependent).

Unfortunately, for Miss McInnis, the government felt that since there was an adult male in her family, her brother, it was he who should be classified as the head of her family even though he was disabled. Following this criteria, she was not able to register for a free homestead given her single status.

Another woman, Isadore Harkness ${ }^{14}$ was thirty-two years old in 1892 when she tried her luck at homesteading. In her case, she indicated on the application form that she was single and that she had dependents (i.e. her mother, sisters and a blind brother). She was given 160 acres to develop and over the course of the next few years, she worked the land and made improvements. By the time that she requested the title on her land, the government had become suspicious and argued that she was not the sole head of her family given that her mother and brother had homesteads of their own. In other words, they felt her application should be cancelled. In the end, given that she had worked the land for a number of years, and that the problem was originally due to government error (i.e. the clerk allowing her to apply even though she was single), she was allowed to keep her homestead and she eventually acquired title.

Theresa Reiter ${ }^{15}$, was another case where government error came into play, however her situation turned out quite differently from Miss Harkness'. She applied for homestead land in 1906, but records indicate that she abandoned the land in 1907 in favour of her brother, John. It is difficult to understand why the government allowed her to apply in the first place given her single status, but perhaps the error was discovered by the local land agent and she was encouraged to abandon her land before official cancellation proceedings against her commenced. $^{16}$ 


\section{Rollings-Magnusson}

Whether these women were successful in their attempt to acquire title or not, it was obvious that they were independent, secure and confident enough in the knowledge that if they had a chance to prove their land, they could also gain title like their male counterparts. ${ }^{17}$ Such beliefs may have been motivated by the social expectation that farm women, including their daughters, needed to be multi-skilled in both the fields and the home. For instance, on the western prairies, there was the socially acceptable norm that married women were essential as working partners on family farms. Not only were they responsible for household chores and the raising of children, but they were also expected to take care of animals and work in the fields alongside their husbands when required, particularly during the spring season when seeding was done and in the fall when harvesting was undertaken. ${ }^{18}$ In fact, it was widely believed that a wife was a very important asset to a male homesteader as he would be far more likely to succeed in gaining title to his property if she was around to assist him with his tasks (Warren, 1917). ${ }^{19}$ Thus, many women were familiar with all aspects of the farming operation, not only in terms of being accustomed to the amount of labour power that was involved, but also with knowing how to manage a homestead. It was through this experience that women and their daughters (who also learned to perform both masculine and feminine chores ${ }^{20}$ believed that they could handle a homestead on their own. ${ }^{21}$

Fortunately, a rare opportunity to acquire and work on their own homestead land (regardless of their marital status) presented itself in 1908 when the federal government implemented the Volunteer Bounty Act. ${ }^{22}$ The original and primary purpose of this Act was to provide assistance to those Canadian men who had volunteered and fought in the Boer War in South Africa between 1899 and 1902. ${ }^{23}$ This assistance included granting soldiers 320 acres of free land (the equivalent of two homesteads) on the western prairies. ${ }^{24}$ Soldiers then had the 
choice of either working the land themselves and following the homestead regulations that were in place at the time (with regard to residency requirements, breaking and cropping the land, and so on) and eventually gaining title, taking an immediate cash payout (scrip) of $\$ 160$, or presenting a substitute (or substitutes) ${ }^{25}$ who were willing to take over responsibility for developing the land. With regard to this latter option, soldiers could sell their right to homestead to another person and then this person (as the substitute), would be required to follow the homestead regulations and gain title for themselves. Given that it was the soldier who had the right to name a substitute, he could sell his land to any adult individual. Since there was no apparent gender restriction in place, it became an option for soldiers to name either male or female substitutes. ${ }^{26}$ As a result, many women (regardless of marital status or number of dependents $)^{27}$ became holders of volunteer bounty land and began the process of homesteading on the prairies. ${ }^{28}$

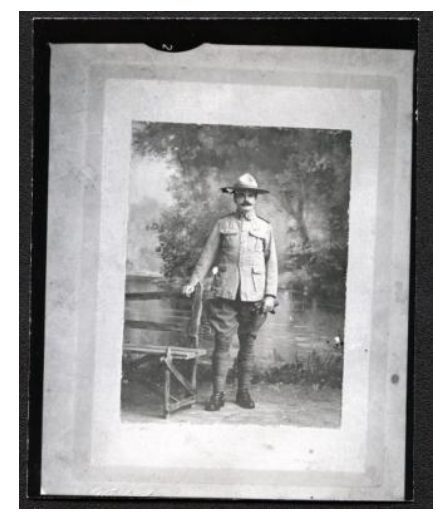

A Boer War Soldier, u.d., SAB, R-A4733 ${ }^{29}$

Given this unique and legitimate way in which women were finally able to register for homesteads, prove, and eventually own their own land, this paper will highlight the experiences of women settlers who acquired Volunteer Bounty land. In particular, attention will be placed on the efforts of single women, their attempts to complete their homestead duties on time and their determination to become landowners of their own quarter-sections in the province of 


\section{Rollings-Magnusson}

Saskatchewan. Acknowledging their efforts through this study will help to complete the picture of western prairie life as it highlights a group of women who were barred from applying for free homesteads as compared to their single male counterparts (under the 1871 Orders in Council and 1872 Dominion Lands Act), and who did not have any dependents or spouses to help them with carrying out their homestead duties. Evaluating their success at gaining title of Volunteer Bounty land will demonstrate that single women could be productive, resourceful, capable, and exclusive owners of their own 160 acres.

\section{Study Methodology}

In order to undertake this study, a review was conducted of the homestead records held by the Saskatchewan Archives Board in Saskatoon, Saskatchewan. These records pertain to all homesteads that were distributed across the province from the beginning of the settlement process in the late 1800 s to the 1930 s. Within this collection of over 395,000 files is a subset of files that relate to the acquisition, distribution and regulatory matters dealing with Volunteer Bounty Land (also known as South African scrip by the Saskatchewan Archives Board).

In order to access these files, a Homestead Index key word search was conducted using the term 'South African scrip'. A total of 4,787 files were found relating to both men and women. In order to analyze a population of single women, a further key word search was done on these files using references to the term 'spinster' or the use of the honorific 'Miss' in the data. Married, divorced, or widowed women were not included as the honorific term of 'Mrs' was used in those files, while the honorific "Mr" was used for men. Given the selections that were made, thirty-seven files became eligible for review.

Upon assessing these thirty-seven files, a further selection was conducted. Any incomplete files, such as those missing military certificates, substitution appointing forms, 
application for entry documents, or sworn statements were deleted from the final count. As a result, twenty-nine files were considered to be appropriate for analysis.

The files were then analyzed for information relating to the date of application, length of residency, the number of acres broken and cropped, and the construction of a home, in order to determine if the women had met all of the statutory performance requirements as set out in the Dominion Lands Act. The issue of whether the female homesteader had successfully obtained title or not was also an essential and important piece of information that needed to be investigated. Any personal data and descriptions of family circumstances that were available in the files were also included in the analysis.

In order to examine this material in an orderly, coherent, and logical way, the data from the homestead files was numerically entered into a statistical software program, SPSS. Variables were created, coding was undertaken, and data entry was performed. Once all of the information had been compiled, it was then possible to identify and discuss any patterns and trends that appeared in the numbers. In addition, to compliment the quantitative analysis and to acquire a more in-depth appreciation of the single women who took on the task of homesteading, examples of individual files pertaining to the particular circumstances of four women will also be examined.

\section{Results}

In order to acquire a snapshot into the lives of the single women who were involved in the homesteading process, it is important to first examine their personal characteristics. In the sworn statements contained within the homestead files, individuals were required to state their age, occupation, place of residence and citizenship. ${ }^{30}$ 


\section{Rollings-Magnusson}

When reviewing the ages of these women, it was evident that there was a gradual decline in the number of women as their age increased. The majority $(44.8 \%)$ were fairly young, as they were between twenty-one and thirty years of age, while $27.6 \%$ were between the ages of thirty-one to forty. Five women (17.2\%) identified themselves as being between forty-one and fifty years of age, with only three single female homesteaders (or 10.4\%) reporting that they were quite a bit older than their counterparts. These three indicated that they were between the ages of sixty-one and seventy years.

When these twenty-nine women were asked to comment about their occupation, twentythree (or $79.3 \%$ ) identified themselves as farmers with three women (or 10.2\%) claiming to hold more than one skill. For example, two reported that they were farmers and housekeepers, while one other stated that she was a farmer and a seamstress. Two other individuals reported holding professional jobs with one indicating that she was a school teacher, while another was a bookkeeper. $^{31}$

With regard to their place of residence, the women in this study lived in a variety of locations across the province. For example, there were two each from Kindersley, Lemsford, Milly, Portreeve, and Moose Jaw while single responses were given for such places as Elbow, Gravelbourg, Radville and Webb.

These women were also asked to comment on whether they were British citizens. Nineteen of them (65.5\%) indicated that they were British subjects, while ten $(34.5 \%)$ reported being naturalized citizens. ${ }^{32}$

\section{The Process of Becoming Homesteaders and Gaining Title}

As set out in the Saskatchewan homestead files, the women within this study obtained land $^{33}$ from Canadian men who had volunteered and fought in the Boer War. It is likely that 
these men decided to sell their land in Saskatchewan, rather than working it themselves, as they preferred to live elsewhere after they returned from South Africa. For example, four individuals indicated that they had relocated to such places as the United States, New Zealand, England, and India. The rest resided in provinces across Canada, with seven living in British Columbia, seven in Ontario, five in New Brunswick and Nova Scotia, and two in Manitoba. ${ }^{34}$

Once the soldier had decided to accept the benefit of the land grant (and the appointment of a substitute), he then had to fill in and submit The Instrument Appointing Substitute form to the Dominion Lands Office. In this form, he had to provide information on his occupation, name of the corps in which he served, and the name of his substitute. His signature also needed to be witnessed. The substitute then filled in the Affidavit in Support of an Application for a Land Grant under the Volunteer Bounty Act, 1908 in which she certified that she was individual who had been appointed by the grantee, and the Application for Entry for a Land Grant under the Volunteer Bounty Act, 1908 where the land description (section, township and range) was set out. Once done, the substitute then became the individual responsible for working and obtaining title to the above noted land. As indicated earlier, there were a number of requirements that individuals had to fulfill before they could acquire title. In 1908, thirty acres needed to be broken and twenty cropped, homes had to be built, and residency requirements all had to be completed within a time frame of three years. If the requirements were not met, the homesteader was in danger of having her application cancelled by the government. ${ }^{35}$

With this opportunity in place, women in this study started applying for homestead land within two years of the Volunteer Bounty Act, 1908 coming into effect. Ten of them (or 34.5\%) submitted an application in 1910, with fifteen more (51.7\%) applying in 1911. Only three applied in 1909 and one made their request in 1913. 


\section{Rollings-Magnusson}

Some women began their homesteading duties immediately by breaking land the same year that they applied, while others broke land in the following years. As such, twelve (or 41.4\%) broke land in 1910, while two worked their land in 1911. Another twelve broke their land in 1912 and three individuals each broke their land in 1913, 1914, and 1915. With regard to how much land they broke in their first year, some women were very successful in their attempts as compared to others. ${ }^{36}$ Sixteen women, the majority, were able to break between one to ten acres of land in their first year, ${ }^{37}$ with seven being able to break eleven to twenty acres. Five women were quite productive by working more than twenty-one acres of land with three of those breaking over thirty acres. Only one managed less than one acre their first year. By the end of their third year of working on the land, twenty-seven out of the twenty-nine women had broken over thirty acres of land with two of them reporting that they had broken the entire 160 acres. In terms of cropping the land within the three year period, all of the women had seeded twenty or more acres of land. ${ }^{38}$

Homestead regulations also set out that settlers had to build a home. As such, given these rules and the need to obtain shelter from the elements, it is not surprising that all of the single women had constructed a dwelling. Such homes were of different sizes and were built of various materials. For example, the most common size of home (reported by four women) was twelve feet by fourteen feet. Three others had each built a fourteen by sixteen foot home, while another three had each built a fourteen by twenty foot structure. The smallest dwelling was eight feet by fourteen feet; the largest was eighteen feet by twenty-four feet. Only two individuals reported constructing an addition onto their homes; both of these structures were twelve feet by fourteen feet in size. 
In terms of the construction material that was used, twenty-eight women (96.6\%) indicated that they had built their home out of lumber, while one individual had built hers out of a combination of lumber and sod. ${ }^{39}$ As for the value of their homes (taking into account the size and the building materials), three stated that their home was worth $\$ 150$, while two reported a value of $\$ 300$. Only one individual felt that their home was worth $\$ 350 .^{40}$ With regard to residency requirements (i.e. living on the land for six months of every year for three years), all of the women successfully achieved this goal.

Female homesteaders also provided information about other improvements that they had made to their land. For example, eleven individuals indicated that they had constructed stables for their animals ${ }^{41}$, three reported that they had built a granary ${ }^{42}$, while seven stated that they had dug a well. One other individual went even further and commented that she had built a pigpen and a henhouse. In terms of other upgrades, twelve women indicated that they had completed some fencing on their land with one acknowledging that she had fenced less than one acre. The others all reported that their land was fully enclosed as all 160 acres had been fenced.

Homesteaders were also asked to describe the stock that they owned. Only thirteen women reported having a small assortment of cattle and/or horses over the years. For instance, one individual reported that she had one horse in 1910, two horses in 1911 and three horses in 1912. Another woman indicated that she had one horse and one cow in 1910, two horses and one cow between 1911 and 1913, and four horses and one cow in 1914. Another individual had only one horse each year, while another only had two cows in $1912 .{ }^{43}$

Given the diligence of these single women in meeting the homestead requirements, it is not surprising to find that all twenty-nine women succeeded in gaining title to their land. Eighteen women received title between 1913 and 1915, while others took a bit longer to obtain 
Rollings-Magnusson

full ownership. Seven women received their title between 1916 and 1918, while four others received theirs between 1918 and $1928 .^{44}$

\section{Individual Cases}

The compiled data set out above offers the opportunity to identify trends and patterns within the single female homesteader population, but it is also important to present individual accounts in order to obtain a clearer picture of life on the prairies. For example, Sarah Birtles ${ }^{45}$, aged sixty-two, was a single woman who eventually acquired title to a homestead, however she had a few minor issues to deal with before she was finally granted full ownership. Miss Birtles had been appointed as a substitute on March 6, 1909 by Ernest Minett who served as a member of the Canadian Mounted Rifles and she applied for entry to the land on March 30, 1910. She began working the land, broke and cropped over the required amounts, and had built a fourteen foot by sixteen foot house and a stable. However, it came to the attention of the local land agent when he did an inspection on June 7, 1913 that she was "short in her two first periods of residence". In particular, when he counted the days, he noticed that she was under the six month time period in the first year by three days and by two days in the second year. He noted that this was due to the fact that she was also carrying out residence duties on another homestead in Alberta. ${ }^{46}$ In other words, as pointed out in a letter to the Department of the Interior in Ottawa on June 18,1913 , the "difficulty appears to be the loss of time consumed in moving from one place to the other." Given that she did not meet the six month residency requirements, it was questioned by the government as to whether her application should be cancelled. On June 27, 1913, F. Nelson, an Assistant Secretary, on behalf of the Dominion Lands Agent in Humboldt, Saskatchewan, wrote a letter to the Department of Interior stating that his office had "decided to accept the manner in which the residence duties had been performed as satisfactory" and that 
they were going to "over-look the shortage in this regard". He also pointed out that the decision in this case would not set a precedent for other similar cases in the future. This argument was accepted by the Department of the Interior and Miss Birtles received title on August 27, 1913.

As compared to Sarah Birtles, Lily Florence Reed ${ }^{47}$, did not encounter any problems with her homesteading experience. She was a bookkeeper who was named as the substitute for Frederick Currie (who had served in the South African Constabulary, E Division) on April 21, 1909. She applied for entry to the homestead in Golden Prairie, Saskatchewan on April 12, 1910. In her sworn statement dated October 23, 1913, she indicated that she was twenty-eight years old, single, and was a British subject by birth. She broke and cropped five acres of land in 1910, broke twenty acres and cropped twenty-five in 1911, and broke ten acres and cropped thirty-five in 1912. She did not own any stock, but she did build an eight foot by fourteen foot house and a granary, and she constructed two miles of fencing around her property. Miss Reed also indicated that she had lived on the land six months of each year for three years from 1910 to 1913 . Given that she had followed all of the homestead regulations, she received title on February 13, 1914. Much like Lily Florence Reed, Alice Switzer ${ }^{48}$, a single twenty-eight year old housekeeper/farmer, was the substitute for Lewis John LeRoy, a volunteer who had served in D Battery of the Royal Canadian Horse Artillary. He appointed her on January 30, 1909 and she applied for entry on March 30, 1910. Miss Switzer broke thirty-five acres and cropped ninetyfive acres between 1910 and $1913^{49}$, built a twelve foot by twelve foot home and fenced ten acres of land. ${ }^{50}$ Given that she had met all of the homestead requirements, she also received title without any problem on March 3, 1914.

Another single woman, Elisabeth Jane Bryce ${ }^{51}$ was the substitute for Charles Jones ${ }^{52}$ who had received his bounty land certificate on March 29, 1910. This thirty-three year old woman 


\section{Rollings-Magnusson}

applied for entry and began breaking and cropping her land. By the end of 1913, she had broken thirty-two acres and cropped seventy-three. She had built a ten foot by sixteen foot home of lumber, but did not have any other buildings and did not own any stock. She received her title on December 2, 1918. What is interesting about this particular case, is that the land had been abandoned in the past (prior to it being set out as soldier settlement land) by a German settler named Joseph Guilliaume. He had applied for entry but found that the land was impossible to farm due to it being "too rough" and as such, he cancelled his application in May, 1909. Given the noted problem with the terrain, it is remarkable that a single woman, like Miss Bryce was able to successfully work the land, follow all of the homestead regulations and eventually obtain title for the property. ${ }^{53}$

\section{Conclusion}

Since all twenty-nine women in this study were able to receive title for their land, it is obvious that these single women were able and competent individuals who had the will and perseverance to comply with, and complete all of, the homestead requirements as set out under the Dominion Lands Act. However, such accomplishments would never have been possible if women had not been named as substitutes by soldiers who fought in the Boer War. By taking advantage of this opportunity, women were able to become homesteaders.

While this event was an achievement for women, the actual fact was that these women were still in a position of having to obtain homestead land through indirect means, rather than receiving it for free. Not only that, but they were also required to meet the homestead requirements or have their application cancelled. In other words, even though they could acquire the title of 'homesteader', there was a clear economic hardship being imposed upon them. As discussed by Georgina Binnie-Clark, a woman who had bought land privately in southern 
Saskatchewan in the early 1900s and who was aware of the gender and economic inequities associated with the homesteading program:

[Farming] should be a highly profitable means of independence and wealth for women as it has always provided for men. But on every side my neighbours had obtained their land as a gift from the government, or at least one hundred and sixty acres of it....in addition to the performance of the homestead duties; in this way a farm in every way equal to the one which had cost me five thousand dollars (1979: 300).

She also went on to say that a woman farmer "has the killing weight on extra payment thrust on her at the very outset. She may be the best farmer in Canada, she may buy land, work it, take prizes for seed and stock, but she is denied the right to claim from the Government the hundred and sixty acres of land held out as a bait to every man" (1979: 300). In other words, even though Georgina firmly believed that single women could compete with their male counterparts if given the opportunity, inherent obstacles would continue to stand in their way that would hamper their success. For example, since men did not have to worry about the initial expenditure associated with having to buy land, they could immediately invest their funds into stock, farm implements, housing and fencing. As such, it was easier for men to comply with the homestead requirements as they could devote their energy directly and quickly into the homestead. Women, on the other hand, began homesteading life in a negative position as they had to deal with the cost of purchasing the land, and then cope with the expense of equipment and materials needed to work the land. In short, this meant that women faced a far higher risk on not being able to successfully gain title to their land within the three year time period as compared to men who did not have to carry the extra financial burden. Given this situation, it is significant that the twenty-nine single women in this study were able to overcome these difficulties, assume their responsibilities as land owners and prove their land and acquire title. 


\section{Rollings-Magnusson}

When a comparison is made between the single women who had bought Volunteer Bounty land to the single men who had made the same kind of purchase in Saskatchewan, it is interesting to note that both sexes completed the same amount of work in similar time frames. For example, William Epler, a thirty-eight year old single male of Big Muddy, Saskatchewan entered his land in July of 1911. By 1915, he had broken and cropped forty-five acres of land, he cared for stock, ${ }^{54}$ had built a twenty-four foot by twenty-six foot home as well as a stable and granary, and he had been able to fully fence his property. ${ }^{55}$ Another male, Francis Mead, a thirty year old from Ogema, Saskatchewan entered his land in December 1909, he broke and cropped sixty and sixty-five acres respectively, had built a twelve foot by forty foot home out of lumber, had fenced forty acres, and in 1910 had seven horses and eight cattle. ${ }^{56}$ Given these results, it is clear that when determined single women entered into a similar situation as their male counterparts, they performed equally well with regard to meeting basic homestead regulations. Perhaps they were women who were willing to assume traditional male working roles, were determined to work hard, and were persistent in their belief that they could complete all of the regulated requirements as set out in the Dominion Lands Act. ${ }^{57}$

What is even more noteworthy is that these single women accomplished in three years what it took an entire family to do in the same time frame. As noted earlier, these single women were alone when they attempted to homestead; that is, according to their sworn statements, they were not married and did not have any children. As ascertained from these documents, they were reliant upon themselves to handle or manage the daily workload. ${ }^{58}$ Others who bought soldier settlement land during the same time period included men and women who had spouses and children to help them with meeting the homestead requirements. Having so many extra hands to help with the farm labour of breaking and cropping land, and building a home for the family and 
shelter for the animals would have substantially decreased the difficulties associated with obtaining title. At the very least, the work involved would have been more equally distributed among all family members rather than the entire workload being handled by one individual.

Such was the case with a married woman named Ida Abbott ${ }^{59}$ who had three children. Mrs. Abbott was thirty-five years old and lived in Kindersley, Saskatchewan. She bought Volunteer Bounty land and applied for the homestead in 1909. In three years, her family had broken thirty-five acres and cropped forty acres. She had three cattle in 1910 and four in 1911 and 1912 and she indicated that her family lived in a framed twelve foot by twenty-four foot home that was worth $\$ 250$. Given these results, Mrs. Abbott, her husband and her children met the homestead requirements and received their patent in 1913. In comparison to the single women noted in this study, the amount of work completed by Ida and her family was about the same as that undertaken by the single women. Given these similar outcomes, it is logical to assume that homesteading was a more challenging task for single women to acquire title (given that they were solely responsible for the work) as compared to those women who had spouses and children to help with farm labour.

Even though life may have been harder for these single women on the prairies, they persisted in their quest to possess their own land. These women found a way to purchase land, they became part of the homesteading program, and they became multi-skilled individuals, not only undertaking the demands of domestic chores but also learning numerous tasks associated with animal husbandry and field work. Without the opportunity provided by the Volunteer Bounty Act, these women would never have been able to take part in the settling of the western Canadian prairies, but given that they were named as substitutes, this provided them with the chance to demonstrate that they were capable, independent and determined individuals who 


\title{
Rollings-Magnusson
}

could succeed in spite of all the problems and constraints that were set in their way. Once they

\author{
held their title in hand, they had proof that they were qualified to hold the prominent status of
}

'homesteader' in the same fashion as any male homesteader in the province of Saskatchewan.

\section{ENDNOTE}

${ }^{1}$ The marital status of 'single' women in this paper refers to the legally defined term of 'spinster' referring to women who have never married and who do not have any children.

${ }^{2}$ For a more detailed discussion of the historical background of the country and the economic and political reasons for settling the west, refer to Creighton (1963), Mackintosh (1939), Martin (1938), and Morton (1938).

${ }^{3}$ The settlement policy was part of a much larger federal government program. This program, known as the National Policy, included the completion of a transcontinental rail line that would link the west and east coasts of the country, the settlement (homestead) policy that would encourage rapid population growth on the prairies, and a tariff policy (in 1879) which would protect Canadian industries by imposing duties on imported goods. See Fowke (1983) and Easterbrook and Aitken (1963).

${ }^{4}$ Manitoba entered into Confederation in 1870, while Alberta and Saskatchewan entered in 1905. For more information on the transition to provincial status, see Dawson and Younge (1940).

${ }^{5}$ According to Lambrecht (1991), over 56 million acres were divided into 160 acre lots for homesteading purposes across the prairies.

${ }^{6}$ A number of people took advantage of this opportunity as there was a great influx of individuals to the region between 1881 and 1911. In fact, over 1.78 million people (men, women, and children) migrated or immigrated to the three provinces during this time period (Sixth Census of Canada, 1921). In terms of ethnic distribution, there were 1,162,831 people of British background (including English, Irish and Scottish) or 60.4\%, 140,022 were of German background or 12\%, 107,757 were Austro-Hungarian (9.3\%), 78,458 were Scandinavian (or 6.7\%), 74,246 were French $(6.3 \%)$, while those who were Jewish, Dutch, or Russian made up less than $3 \%$ of the population each $\left(5^{\text {th }}\right.$ Census of Canada, 1911).

${ }^{7}$ To be classified as the 'head of a household', a woman would have to prove that she was widowed, divorced, or abandoned and that she had children (under the age of 18) who lived with her and were dependent on her. In addition, she had to ensure that no other adult male relative lived with her, otherwise this person would be seen as the head of the household (Lambrecht, 1991).

${ }^{8}$ Women were not defined as 'persons' until years later. This issue was brought to the forefront in 1927 by the 'famous five': Emily Murphy, Henrietta Muir Edwards, Louise McKinney, Irene Parlby, and Nellie McClung. At that time, they proceeded with petitioning the Government of Canada, and eventually had their case heard by the Supreme Court of Canada who decided, unanimously, that women were not to be defined as 'persons'. The five women then appealed to the British Privy Council and the Court of Appeal for Canada and finally on October 18, 1929, it was decided by the court that the term 'persons' included both men and women (Benoit 2006, Online).

${ }^{9}$ Cavanaugh (1993: 204) suggested that the program was worded to "ensure that, in the newest of the provinces, land, and therefore wealth, [would be] overwhelmingly owned and controlled by men, reinforcing a traditional patriarchal social order that dictated a dependent womanhood." What this meant was that women on the prairies who were married were expected to be compliant, obey their husbands, and take care of their children on the homestead. Single women were to find suitable feminine related jobs such as working as domestics in other people's homes, as cooks or chambermaids in hotels, as kitchen help, dining room workers or ward maids in 
hospitals, or teachers in schools rather than becoming property owners like men (Rasmussen et.al., 1979; LindstromBest, 1986).

${ }^{10}$ Given that the homestead program was created in 1871 , men had enjoyed the rights to free homestead land for almost 60 years. As such, there was very little land left over for women to homestead.

${ }^{11}$ For details on the boom and bust cycle of the wheat economy on the prairies during the 1920s and 1930s, see Fowke (1983).

${ }^{12}$ Women had few rights economically, politically, or socially during the time of the homesteading era. Along with the restrictions placed on them with regard to the homesteading program, they were unable to vote in federal, provincial or municipal elections, they could not sit on juries, and they were not the legal guardians of their own children. They could not create a will unless they had their husband's consent, and they could not sign contracts, or have any legal input as to the selling of family property. For more information on how Canadian women's lives were constrained and impacted by the law, see Kealey and Sangster's edited collection Beyond the Vote: Canadian Women and Politics (1989), Ursel's book Private Lives, Public Policy: 100 Years of State Intervention in the Family (1992) and Rasmussen et.al.'s book A Harvest Yet to Reap (1979). For details on the impact of the law on pioneer women in particular, see Rollings-Magnusson (1999).

${ }^{13}$ Saskatchewan Archives Board, Homestead File No. 671992.

${ }^{14}$ Saskatchewan Archives Board, Homestead File No. 317719

${ }^{15}$ Saskatchewan Archives Board, Homestead File No. 45811A

${ }^{16}$ This suggestion is speculative as there is no official documentation pertaining to this issue in the file.

${ }^{17}$ For a fuller discussion of the circumstances surrounding these women, see Rollings-Magnusson (2009a).

${ }^{18}$ See Kohl (1976), Sachs (1983) and Silverman (1984).

${ }^{19}$ Lindgren (1991) and Riley (1988), who both studied the American situation agreed that it was this dual working ability of women that placed them in such high demand as wives. Being able to perform both masculine and feminine tasks were essential give the numerous jobs that needed to be done around the farmyard and in the fields.

${ }^{20}$ Riley (1988) offers an interesting point about women assuming male gender roles. She suggests that this behavior was learned by girls at an early age when they were expected to perform both boys' and girls' work on the farm. Girls, she said, not only learned all of the typical domestic chores associated with the home, but that they were also expected to herd stock, milk cows, ride horses that were pulling a thresher, and hunt and trap wild game.

21 This belief may be what motivated an individual like Georgina Binnie-Clark (1979) to acquire farmland. She was a single woman who wished to homestead but given legislative restraints, she ended up purchasing land in Fort Qu'Appelle, Saskatchewan. Between 1905 and 1908, she reported on her achievements (including her ability to obtain record profits) and offered her opinions about the homesteading program in the province. She argued that the homesteading program was unfair as it benefitted single men over single women, that women were at an economic disadvantage when they had to buy their farms as compared to men who received theirs for free, and that women could be highly successful at homesteading if only they were given a "fair start" with their male counterparts (1979: $\mathrm{xx}$ ). She also stressed the point that women could be self-sufficient as they had the ability to learn a wide range of skills relating to both domestic chores and fieldwork. Given her accomplishments and her outspoken opinions, Miss Binnie-Clark may have played a significant role in encouraging other single women in the province to become autonomous and self-supporting farmers. Another influential factor that may have persuaded women in Saskatchewan to become landowners on their own quarter-sections, was the fact that American women (whether they were single, divorced, widowed or abandoned) could apply for their own free 160 acres of homestead land across the prairie and plains regions of the United States. This policy, known as the Homestead Act of 1862, treated 
men and women in an equitable fashion and as a result, inspired and encouraged women to gain independence through property ownership (Smith 1991; Riley 1977; Garceau 1995).

${ }^{22}$ Volunteer Bounty Act, 1908 (S.C. 1908 7-8 Edward VII c. 67).

${ }^{23}$ The Boer War (also known as the South African War) was actually a fight between the Dutch (re. the Boers) who had settled in two areas (the Transvaal and the Orange Free State) outside of the British occupied Dutch settlement of the Cape of Good Hope. Political antagonisms between these two groups erupted throughout the 1800s as Britain wanted control over the Transvaal, particularly after the discoveries of diamonds and gold in the area. They eventually annexed the Transvaal in 1877 and as a result, tensions grew higher and higher between the Boers and Great Britain with a war between them beginning in 1899. Given Canada's close ties to Great Britain (re. being a colonial country), the Canadian government sent a battalion of volunteers to serve with the British in South Africa. Over the three year time period of the war, over 7,000 Canadian men fought in the battles that ensued with 267 being killed in action (Canadian War Museum, 2009). For more information on the Boer War, see Lotz (2000), Evans (2000), Price (1972), and Farwell (1976).

${ }^{24}$ It should be noted that Canadian nurses who had taken part in the Boer War were also eligible to receive land under the Volunteer Bounty Act, however, in this study no nurses were involved with selling their homestead land to single women.

${ }^{25}$ It was a requirement of the Volunteer Bounty Act, 1908 that substitutes had to be British subjects or be willing to declare their intention to become British subjects, and they had to be at least 18 years old.

${ }^{26}$ While there was no explanation as to why the term 'persons' was not included in the Act, or why no gender distinction was in place, it could be surmised that since the soldiers had gone to war in the name of the country, and had placed themselves in danger, that the government felt that it would be inappropriate to put conditions on who they could select as substitutes.

${ }^{27}$ According to the Saskatchewan Archives Board, 628 files relate to women who had acquired scrip from soldiers. (See http://www.saskhomesteads.com/).

${ }^{28}$ In the circumstances where the soldier had been killed in the war, or if they had died shortly after the war, the benefits associated with the Volunteer Bounty Act would be passed on to the soldier's legal representative (i.e. his widow or his mother or father). For example, George Casey Doyle had been a private with the $3^{\text {rd }}$ Canadian Mounted Artillery and had been discharged. He died of internal hemorrhage (rupture of the liver) in 1903. Given that his father had previously passed away, and he had no brothers or sisters, his heir was his mother, Jennie Doyle (who had been married twice and was now a widow). She applied for the homestead on June 14, 1909, met the homestead requirements, and received her patent on June 27, 1913. (See Homestead File \#1733160, Saskatchewan Archives Board.)

${ }^{29}$ C. Steedman in Uniform for the Boer War.

${ }^{30}$ Questions relating to family members were also included in the documents. However, given the focus of this research, those who claimed to be married, widowed, abandoned, or have dependents were excluded from this study.

${ }^{31}$ It was not surprising to find that few women in this study held jobs as the social expectation in the late 1800s and early 1900s was that women would live with their parents until they married. For those single women who were employed, many tended to work as domestics in the local towns or on neighbouring farms, while others worked in the teaching field, or in hotels, boarding houses and restaurants. These jobs were socially acceptable as they were seen as being an extension of a woman's natural housework abilities. Few women worked in office settings as these positions were seen as being a male domain (Prentice, Bourne, Brandt et.al. 1988).

${ }^{32}$ Unfortunately, no further details were provided regarding citizenship. For example, while naturalized applicants only had to report on their status, they did not have to provide any details on their country of origin or when they immigrated to Canada or how long they had been in the country. 
${ }^{33}$ While it has been determined by the Saskatchewan Archives Board that this land was sold to the substitute (see the online files pertaining to South African Scrip at www.saskhomesteads.com), there is no information in any of the homestead files that gives an account of the bill of sale. As such, no data is available on the date of purchase or the purchase price.

${ }^{34}$ Only four men mentioned that they had returned and were residing in Saskatchewan. However, there was nothing in the files that explained why they had decided to sell their homestead, rather than working it themselves. It is likely that they believed that they could obtain a higher profit for it if they sold the right to homestead privately.

${ }^{35}$ When the homesteader filled in a request for the patent to their land (i.e. their certificate of title), they had to include sworn statements; one of which had to be filled out by the homesteader, while the other two were completed by witnesses. The documents required information relating to the marital status of the homesteader, how much land was broken and cropped, the portion of the year that the homesteader had been on the land, the number and type of stock, size of the house and cash value, the extent of fencing, and what other buildings had been constructed. Witnesses also had to set out their own occupation, how long they had known the applicant, and where they resided. If any information was missing or if there seemed to be a problem with the file (i.e. not enough land broken or cropped, or if the time limit on residency was short), then an inspector would be sent out from the Dominion Lands Office to the homestead to conduct an inspection. If he found that the requirements were not met, he would begin cancellation proceedings with the federal Department of the Interior in Ottawa. See, for example, the homestead file relating to Birtles (File No. 108200A).

${ }^{36}$ For some women, this process may have taken more time due to the nature of the land that they acquired. Extra time would be needed if the land was full on stones or large rocks, or if trees and shrubs (and their roots) needed to be removed before actual breaking of the land could begin. Also, they may have decided to build shelter first before starting the work on the land, particularly if the winter months were quickly approaching.

${ }^{37}$ If a homesteader broke 10 acres of land each year, they would average 30 acres over the three years (the minimum requirement under the homestead regulations.)

${ }^{38}$ Many homesteaders grew wheat as their primary crop. See Fowke (1983) for a discussion of the wheat economy during the pioneer era.

${ }^{39}$ In general, homesteaders tended to use whatever materials were handy in order to build their homes. If they obtained land which had trees, then they tended to build log homes while those who had treeless lots would cut sod out of the land and build soddies. If the homesteader had a bit of extra money, they could purchase cut timber from the local town and build framed houses (Rollings-Magnusson 2009b).

${ }^{40}$ Only six women included information in their sworn statements about the value of their homes.

${ }^{41}$ The majority of stables were approximately 28 feet long by 28 feet wide with the largest being 28 feet by 32 feet. Only one individual claimed to have a smaller stable (at 14 feet by 14 feet).

${ }^{42}$ One homesteader had a 4 foot by 6 foot granary, while another had one that was 14 feet by 16 feet. The third homesteader did not elaborate on the size.

${ }^{43}$ Having stock would be a sign to the Dominion Lands Office that the homestead was a productive one and as such, could be the reason for why they included this question in their documents. For those homesteaders who had horses, it is likely that the horses were used for ploughing and other field work as well as for transportation purposes, while the cows were used to supplement the family diet with milk, butter, and cheese.

${ }^{44}$ There were no reasons given in the files as to why some women took longer than the three years to apply for title. It may be the case that they met all of the homestead requirements within the given time frame, however due to distance, climate or other obstacles, they may not have had the opportunity to travel to the land office until months or years later. 


\section{Rollings-Magnusson}

${ }^{45}$ Saskatchewan Archives Board, Homestead File No. 108200A.

${ }^{46}$ There are no details in the file as to how she acquired a second homestead or where it was located in Alberta.

${ }^{47}$ Saskatchewan Archives Board, Homestead File \#1696487.

${ }^{48}$ Saskatchewan Archives Board, Homestead File \#1697804.

${ }^{49}$ There was no information in the files to explain the inconsistency between the number of acres broken and the number of acres cropped, however it may be possible that much of the land was ready for cropping due to clearing by fire.

${ }^{50}$ She did not report having any stock.

${ }^{51}$ Saskatchewan Archives Board, Homestead File 1845993.

52 There was no indication in the files as to what division he served with during the Boer War.

${ }^{53}$ Although there were no details provided in the file with regard to how rough the land was, it is likely that Elisabeth had a number of difficulties when trying to ready the ground for cropping. She may have had to clear the land of gravel, remove large boulders, cut down trees and pull up roots and/or she may have had to spend time leveling the land so that it could be plowed. Either way, the work would have been quite labour intensive and needed to be done in a timely fashion so that she could prove her land within the three year period.

54 This individual did not provide specifics as to how many or what types of stock he owned.

55 Saskatchewan Archives Board, Homestead File No. 2169999.

${ }^{56}$ Saskatchewan Archives Board, Homestead File No. 1747456.

${ }^{57}$ It is interesting to note that in the American situation, women were found to be quite capable of managing their own 160 acres of homestead land. For example, Lindgren (1991) in her study reported that some women felt that working in the fields was actually easier than undertaking household work as fieldwork took less physical labour than the drudgeries associated with domestic chores. Other women in her study indicated that they were used to working hard and could work "as hard as any man and could do all sorts of heavy jobs" (121). Sannes (1993), Jeffrey (1998), and Patterson-Black (1976) also highlighted the fact that women were eager to claim and work their own land and were excited by the prospect of becoming property owners, rather than being forced to accept such feminine positions as wife and mother, housekeeper, cook, teacher or nurse.

${ }^{58}$ While there was no evidence in the homestead files to suggest that the 29 women had help with proving their land, it is possible that they had extended family members or friends who would visit from time to time to assist them. Such was the case with some single female American homesteaders as set out by Lindgren (1991). It could also be argued that rather than trying to eke out a living on their homestead, some single women may have relied on savings that they had acquired from previous occupations, or they continued with paid work while they homesteaded. Thus, they would have funds to pay for farm labourers to help them out with their chores. See Patterson-Black (1976) and Kohl (1986) who both reported in their studies finding single women who had medical practices or who worked as teachers in schools.

${ }^{59}$ Saskatchewan Archives Board, Homestead File No. 1691577. 


\section{REFERENCES}

Abbott, Ida. 1913. File \# 1691577. Saskatchewan Archives Board: Saskatoon, SK.

Benoit, Monique. 2006. "Are Women Persons? The "Persons" Case." Library and Archives Canada, http://collectionscanada.ca/publications/archivist-magazine/015002-2100-e.html.

Binnie-Clark, Georgina. 1979. Wheat and Woman. Toronto: University of Toronto Press.

Birtles, Sarah. 1913. File \#108200A. Saskatchewan Archives Board: Saskatoon, SK.

Bryce, Elisabeth J. 1918. File \#1845993. Saskatchewan Archives Board: Saskatoon, SK.

Canadian War Museum. 2009. "Canada and the South African War (Boer War), 1899-1902." http://www.warmuseum.ca/cwm/exhibitions/boer/boerwarhistory_e.shtml

Cavanaugh, C. 1993. "The Limitations of the Pioneer Partnership: The Alberta Campaign for Homestead Dower, 1909-1925." Canadian Historical Review, 74, no. 2: 198-225.

Creighton, Donald Grant. 1963. British North America at Confederation: A Study Prepared For the Royal Commission on Dominion-Provincial Relations. Ottawa: Queen's Printer.

Dawson, C.A. and Eva Younge. 1940. Pioneering in the Prairie Provinces: The Social Side of the Settlement Process. Toronto: Macmillan of Canada.

Doyle, Jennie. 1913. File \#1733160. Saskatchewan Archives Board: Saskatoon, SK.

Easterbrook, W.T. and Hugh G.J. Aitken. 1963. Canadian Economic History. Toronto: MacMillan of Canada.

Epler, William. File \# 2169999. Saskatchewan Archives Board: Saskatoon, SK.

Evans, Martin M. 2000. Encyclopedia of the Boer War. Oxford: ABC-CLIO.

Farwell, Byron. 1976. The Great Anglo-Boer War. New York: Harper and Row Publishers.

Fifth Census of Canada, 1911. Ottawa, Ontario.

Fowke, Vernon. 1983. The National Policy and the Wheat Economy. Toronto: University of Toronto Press.

Garceau, D. 1995. "Single Women Homesteaders and the Meanings of Independence: Places On the Map, Places in the Mind." Frontiers, 15, no. 1: 1-25.

Harkness, Isadore. 1895. Homestead File \#317719. Saskatchewan Archives Board: Saskatoon, 
SK.

Jackel, Susan. 1979. "Introduction." In Wheat and Woman, (author) Georgina Binnie-Clark, v-xxxvii. Toronto: University of Toronto Press.

Jeffrey, Julie Roy. 1998. Frontier Women: Civilizing the West, 1840-1880. New York: Hill and Wang.

Kealey, Linda and Joan Sangster (eds.). 1989. Beyond the Vote: Canadian Women and Politics. University of Toronto Press: Toronto.

Kohl, Edith Eudora. 1986. Land of the Burnt Thigh. St. Paul: Minnesota Historical Society Press.

Kohl, Seena. B. 1976. Working Together: Women and Family in Southwestern Saskatchewan. Toronto: Holt, Rinehart and Winston of Canada.

Lambrecht, Kirk. 1991. The Administration of Dominion Lands, 1870-1930. Regina: Canadian Plains Research Center.

Lindgren, H. Elaine. 1991. Land in her own Name: Women as Homesteaders in North Dakota. Fargo: The North Dakota Institute for Regional Studies.

Lindstrom-Best, V. 1986. "I won't be a Slave: Finnish Domestics in Canada, 1911-30." In Looking into my Sister's Eyes: An Exploration in Women's History, ed. J. Burnet, 33-54. Toronto: The Multicultural History Society of Ontario.

Lotz, Jim. 2000. A Century of Service: Canada's Armed Forces from the Boer War to East Timor. Dartmouth: Print Canada.

Mackintosh, William. A. 1939. The Economic Background of Dominion Provincial Relations: A Study Prepared for the Royal Commission on Dominion-Provincial Relations. Ottawa: King's Printer.

Martin, Chester. 1938. History of Prairie Settlement: "Dominion Lands” Policy. Toronto: MacMillan Company of Canada Limited.

McInnis, Isabella. 1910. Homestead File \#671992. Saskatchewan Archives Board: Saskatoon, SK.

Mead, Francis. Homestead File \#1747456. Saskatchewan Archives Board: Saskatoon, SK.

Morton, Arthur S. 1938. History of Prairie Settlement. In Canadian Frontiers of Settlement (9 Volumes), eds. W.A. Mackintosh and W.L.G. Joerg, Vol. 2 Pt 1. Toronto: Macmillan of Canada. 
Patterson-Black, Sheryll. 1976. "Women Homesteaders on the Great Plains Frontier." Frontiers: A Journal of Women Studies, 1, no. 2: 67-88.

Prentice, Alison, Bourne, Paula, Cuthbert-Brandt, Gail, Light, Beth, Mitchison, Wendy, and Naomi Black. 1988. Canadian Women: A History. Toronto: Harcourt Brace Jovanovich.

Price, Richard. 1972. An Imperial War and the British Working Class: Working-Class Attitudes and Reactions to the Boer War, 1899-1902. Toronto: University of Toronto Press.

Rasmussen, Linda, Rasmussen, Lorna, Savage, Candace and Anne Wheeler. 1979. A Harvest Yet to Reap. Toronto: The Women's Press.

Reed, Lily F. 1914. Homestead File \#1696487. Saskatchewan Archives Board: Saskatoon, SK.

Reiter, Theresa. 1907. Homestead File \#45811A. Saskatchewan Archives Board: Saskatoon, SK.

Riley, Glenda. 1988. The Female Frontier: A Comparative View of Women on the Prairies and the Plains. Lawrence: University of Kansas.

Riley, G. 1977. "Images of the Frontierwoman: Iowa as a Case Study." The Western Historical Quarterly,April: 189-202.

Rollings-Magnusson, S. 2009a. "Spinster's Need Not Apply: Six Single Women who Attempted to Homestead in Saskatchewan between 1872 and 1914." Prairie Forum, 34, no. 2: 357-81.

. 2009b. Heavy Burdens on Small Shoulders: The Labour of Pioneer

Children on the Canadian Prairies. Edmonton: University of Alberta Press.

. 1999. "Hidden Homesteaders: Women, the State, and Patriarchy in the Saskatchewan Wheat Economy, 1870-1930.” Prairie Forum 24 (2): 171-183.

Sachs, Carolyn E. 1983. The Invisible Farmers: Women in Agricultural Production. Totowa: Rowman and Allanheld.

Sannes, Erling, N. 1993. "Free Land for All: A Young Norwegian Woman Homesteads in North Dakota." North Dakota History, 60, Spring: 24-28.

Silverman, Eliane L. 1984. The Last Best West: Women on the Alberta Frontier, 1880-1930. Montreal: Eden Press.

Sixth Census of Canada, 1921. Ottawa, Ontario 
Smith, S.L. 1991. "Single Women Homesteaders: The Perplexing Case of Elinore Pruitt Stewart." The Western Historical Quarterly, 22, no. 2: 163-83.

Switzer, Alice. 1914. File \#1697804. Saskatchewan Archives Board. Saskatoon: SK.

Ursel, Jane. 1992. Private Lives, Public Policy: 100 Years of State Intervention in the Family. Women's Press: Toronto.

Volunteer Bounty Act, 1908. S.C. 1908 7-8 Edward VII c.67.

Warren, George F. 1917. Farm Management. New York: Macmillan. 